Головне управління персоналу Генерального штабу Збройних Сил України, Київ

\title{
Методичний підхід до формулювання задачі синтезу і оцінювання ефективності функціонування перспективної системи кадрових органів під час комплектування військ особовим складом
}

Резюме. У статті висвітлено фактори, які впливають на вдосконалення системи комплектування збройних сил особовим складом, визначено головне завдання перспективної системи кадрових органів та запропоновано основи синтезу i оцінювання ефективності функціонування перспективної системи кадрових органів під час комплектування військ особовим складом.

Ключові слова: комплектування військ особовим складом; система кадрових органів; синтез системи; ефективність функціонування.

Постановка проблеми. На сучасному етапі розвитку Збройних Сил України існуюча система комплектування військ особовим складом потребує вдосконалення. Потреба вдосконалення цієї системи обумовлена наявністю таких факторів:

результати науково-технічного прогресу суспільства сприяють подальшому оснащенню військ сучасним озброєнням i високотехнологічною військовою технікою, зокрема інформативно-аналітичними системами;

необхідність підвищення ефективності обслуговування і бойового застосування сучасного озброєння і військової техніки висококваліфікованим особовим складом;

актуальність визначення та впровадження ефективних методів удосконалення системи обліку потенціальних можливостей поповнення збройних сил особовим складом, удосконалення підсистеми мобілізації особового складу та його розподілу за видами i родами військ та спеціальностями;

створення та подальше застосування швидкодіючих методів і засобів обробки інформаційних потоків щодо обліку особового складу для збройних сил, 3 метою його подальшої підготовки та відмобілізування.

Головним завданням перспективної системи кадрових органів на відміну від існуючої, є запобігання негативних впливів деяких 3 указаних реальних факторів на повноцінне комплектування військ кваліфікованим особовим складом після його підготовки, перепідготовки та проведення заходів мобілізації в особливий період 3 мінімальними витратами часу і фінансів.

Динаміка зростання сучасних вимог до підсистеми мобілізації, для всебічного комплектування збройних сил особовим складом, нарешті, реальна практика мобілізації кадрів в останні роки, все це потребує оновлення системи комплектування на науковій основі. Відсутність обгрунтованих адекватних рекомендацій для системи кадрових органів спричиняють проблему, яка потребує розв'язання.

Аналіз останніх досліджень і публікацій. Система комплектування військ особовим складом найбільш розкривається у працях не тільки українських, але i закордонних вчених, оскільки саме провідні країни світу $€$ місцем зародження й динамічного розвитку системи прийняття рішень в умовах невизначеності випадкового i антагоністичного типу $[3,4,8,10]$.

$$
\text { У роботах }[1,2,5-7,9] \text { надані }
$$
фундаментальні загальнонаукові основи розв'язання проблем кадрового забезпечення. Проте специфіка системи комплектування збройних сил, пiі виключно динамічний, швидкозмінний за часом характер, необмежений розподіл у просторі та за обсягом, викликає необхідність вирішувати завдання порівняння, відбору i комплектування на основі нового методичного підходу з урахуванням військової специфіки.

Метою статті $\epsilon$ висвітлення нового методичного підходу до формулювання задачі синтезу та оцінювання ефективності функціонування перспективної системи кадрових органів для більш якісного комплектування військ особовим складом.

Виклад основного матеріалу. Постановка завдань синтезу $i$ оиінювання ефективності системи кадрових органів. Функціонуюча ефективна та швидкодіюча система кадрових органів, яку доцільно теоретично віднести до розташованої у просторі складної системи обслуговування, має бути пов'язана з організацією і постійним 
та узгодженим функціонуванням сукупності таких основних потоків: інформаційним, фінансовим і транспортним. Особливості двох останніх потоків є традиційно звичними і не потребують додаткового визначення. Водночас вони потребують узгодженого функціонування 3 іншими потоками для оптимізації процесу мобілізації особового складу за критерієм зменшення загальних фінансових витрат.

Функціонування перспективної системи, яка повинна бути синтезована, має всі ознаки типової системи управління, що діє за законами кібернетики [1]. Ця система кадрових органів містить: орган управління для прийняття рішень, об'єкт управління, канал прямого зв'язку для передачі командної інформації та канал зворотного зв'язку для передачі інформації стану об’єкта управління. Вона діє відповідно до закону необхідної різноманітності та швидкодії. Зміст цього закону визначає, що для досягнення мети функціонування складної системи необхідно, щоб система містила достатньо різноманітний набір іiі протидій збудженням, що виникають iз зовні або зсередини цієї системи [1].

Зважаючи на закон, існує три необхідні умови для нормального управління системою:

достатність інформаційних зв'язків у системі зверху до низу і навпаки;

достатність швидкодії системи (своєчасність відгуку системи на збудження ззовні або зсередини системи);

відповідність рішень, що приймаються, умовам, що складаються, та наявність заходів, які потрібні для задовольняння цієї умови (підготовка персоналу системи; вибір персоналу, який спроможний обгрунтовувати та приймати доцільні рішення і прогнозувати наслідки таких рішень; корекція діяльності персоналу; його ротація тощо).

Інформаційний потік системи кадрових органів - це сукупність зовнішньої та внутрішньої інформації, яка необхідна для управління процесом мобілізації та для поточного контролю якості їі функціонування. Інформаційний потік може здійснюватися у вигляді паперових та електронних документів.

Фінансовий потік - це спрямований рух коштів у системі кадрових органів, який $є$ необхідним для забезпечення ефективного руху відповідних транспортних потоків.

Вказані потоки організовує підсистема управління системою кадрових органів. Ефективність роботи цієї підсистеми повністю залежить від змісту і повноти інформаційних зв'язків у системі, що є необхідною умовою для управління та безпосереднього впливу на досягнення головної мети функціонування системи кадрових органів. Саме тому постановку завдань аналізу і синтезу системи кадрових органів доцільно зробити на основі загальної функціональної схеми інформаційних потоків, які діють у системі, перетворюються цією системою в иï управляючі параметри та сприяють дотриманню двох останніх необхідних умов для функціонування системи, а саме умови достатності швидкодії системи та умови відповідності рішень, що приймаються в системі, ситуаціям, які виникають у кожній конкретний час іiі функціонування [1].

Введемо параметри інформаційних потоків системи кадрових органів у вигляді:

$$
U=\left\{u_{1}, u_{2}, \ldots, u_{r}\right\}-\text { вхідні дані (потреби }
$$

військ щодо комплектування професійноспеціальними та іншими спеціалістами), що потрапляють в систему кадрових органів у складі інформаційних потоків, які узагальнює автоматизована система збору i передачі інформації від штабів, військ і регіональних військових комісаріатів (центрів комплектування та соціальної підтримки);

$r$ - порядкові номери видів професійних категорій особового складу та їх потрібної кількості під час комплектування військ в особливий період, під час підготовки та під час застосування військ за призначенням;

$$
V=\left\{v_{1}, v_{2}, \ldots v_{r}\right\}-\text { параметри }
$$

зовнішнього середовища (поточні дані про спеціалістів, яких може бути підготовлено у військових навчальних закладах; потенційні можливості особового складу, який може бути мобілізовано; терміни мобілізації в регіонах; відомості про спеціальності та спеціалізації даного особового складу; дані про економічні та природні умови в регіонах, які можуть негативно впливати на швидкість мобілізації в умовах нестачі транспортних засобів, які застосовуються для відмобілізування військ тощо);

$$
S=\left\{s_{1}, s_{2}, \ldots, s_{r}\right\} \text { - внутрішні параметри }
$$
системи кадрових органів;

$$
X=\left\{x_{1}, x_{2}, \ldots, x_{q}\right\}-\text { параметри }
$$

управління інформаційними потоками для комплектування військ в особливий період та управління перспективною системою кадрових органів;

$$
Y=\left\{y_{z}, y_{z-1}, \ldots, y_{1}\right\} \text { - вихідні параметри }
$$
(характеристики) особового складу, який направлено для комплектування військ 
ієрархічними підсистемами в системи кадрових органів;

$$
F_{s}=\left\{f_{1}, f_{2}, \ldots, f_{n}\right\}-\text { функціонал }
$$

перетворення інформаційних потоків у потік вихідних параметрів комплектування військ особовим складом перспективною системою кадрових органів;

$$
q, z, n \text { - індекси, що визначають }
$$

кількість і номер параметрів залежностей $X$, $Y$ i $F$;

$$
C(Y) \text { - показник }
$$

ефективності

функціонування системи кадрових органів, який, як правило, відповідає ефективності укомплектування військ випускниками навчальних закладів із професійноспеціальними компетенціями та мобілізованим особовим складом, зокрема спеціалістами 3 резерву, та може бути пропорційним досягненню мети комплектування військ в особливий період.
Цей показник доцільно представити у вигляді функції від сукупності вихідних параметрів системи кадрових органів, тобто від сукупності параметрів забезпеченості дій військ якісним особовим складом у потрібній кількості.

Показник $C$ ефективності $є$ функцією вектора $Y$ вихідних параметрів системи, який, зі свого боку, залежить від функціонала $F_{s}$ перетворення інформаційних потоків $U, V$ та параметрів $X$ управління потоками для комплектування військ в особливий період.

Отже, показник ефективності функціонування системи кадрових органів $C(Y)$ дорівнює

$$
C=\left\{c_{z}, c_{z-1}, \ldots, c_{1}\right\}=C(Y)=C\left\{F_{s}(U, V, X\}\right.
$$

Загальну функціональну схему перетворень інформаційних потоків системи кадрових органів наведено на рис. 1.

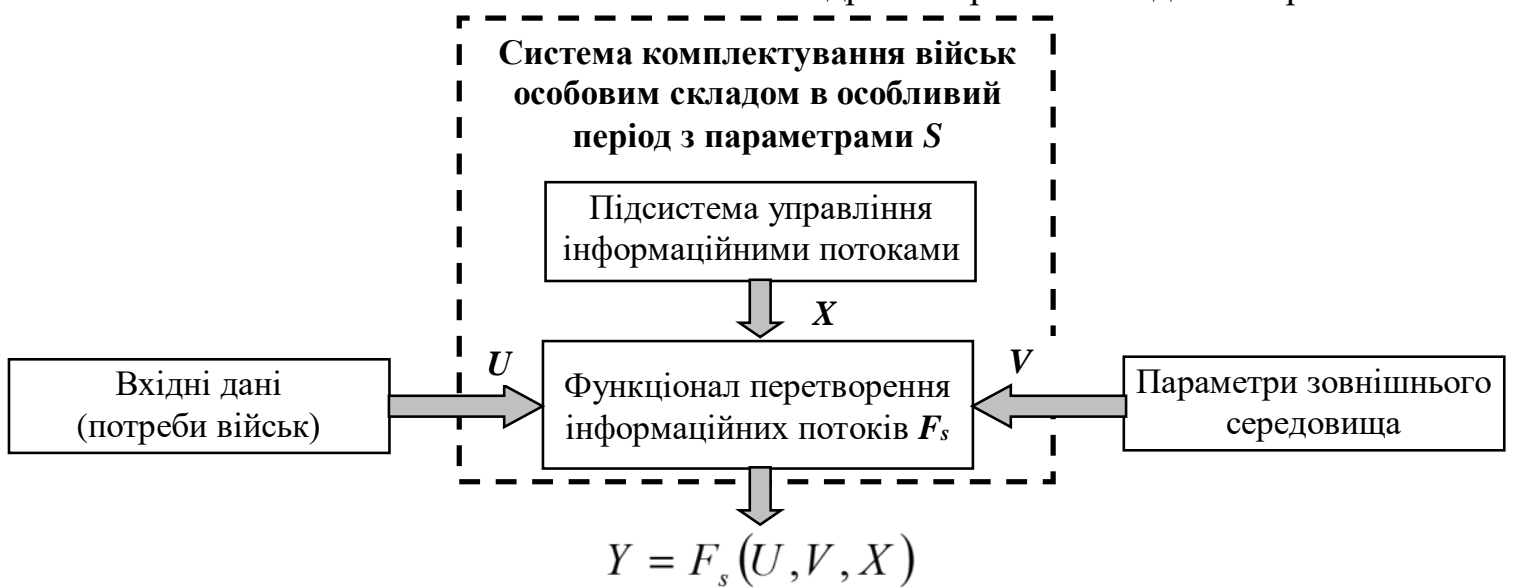

Рис. 1. Загальна функціональна схема перетворення інформаційних потоків у системі кадрових органів

Математичне формулювання завдання аналізу системи кадрових органів. Формулювання завдання аналізу системи кадрових органів виникає у тому випадку, якщо деякий варіант системи необхідно оцінити 3 огляду на його ефективність порівняно $з$ іншим альтернативним варіантом для вибору кращого.

Вектори параметрів системи та інформаційних потоків мають вигляд (рис. 2):

структура системи 3 ii внутрішніми параметрами $S=\left\{s_{1}, s_{2}, \ldots, s_{r}\right\}$;

вхідні дані від військ у систему кадрових органів $U=\left\{u_{1}, u_{2}, \ldots, u_{r}\right\}$; вектор параметрів впливу зовнішнього середовища $V=\left\{v_{1}, v_{2}, \ldots, v_{r}\right\}$;

вектор параметрів управління системою кадрових органів $X=\left\{x_{1}, x_{2}, \ldots, x_{q}\right\}$;

вектор вихідних параметрів системи кадрових органів $Y=\left\{y_{z}, y_{z-1}, \ldots, y_{1}\right\}$.

Знаходження вектора вихідних параметрів у системі кадрових органів здійснюється в системі лише за допомогою алгоритму $F_{s}$ функціонування конкретної системи $S$ після ії побудови.

Це конкретне завдання виходить за межі дослідження, тому не розглядається у цій статті. 


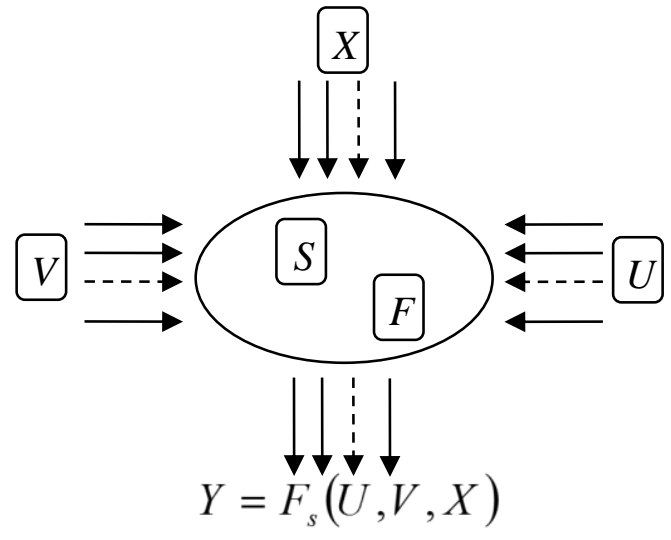

Рис. 2. Схема інформаційних потоків у системі кадрових органів

Визначення алгоритму обчислення векторного показника ефективності функціонування системи кадрових органів $C=\left\{c_{1}, c_{2}, \ldots, c_{n}\right\}, \quad$ тобто показника ефективності комплектування особовим складом та визначення складових параметрів цього показника ефективності, який $є$ цільовою функиією модернізаиії системи кадрових органів повністю пов'язане с алгоритмом функціонування $F_{s}$ та має загальний вигляд:

$$
C=\left\{c_{z}, c_{z-1}, \ldots, c_{1}\right\}=C\left\{F_{s}\left(U_{n}, V_{n}, X\right)\right\} .
$$

Ця залежність означає, що алгоритм визначення показника ефективності функціонування системи кадрових органів (2) спричиняє необхідність формування сукупності параметрів $X$ управління потоками і системою за допомогою функціонала $F_{s}$ перетворення інформаційних потоків у потік вихідних параметрів забезпечення військ системою в точному узгодженні цих параметрів $X_{3}$ вхідними від військ параметрами $U$ потреб в комплектуванні їх та в узгодженні із зовнішніми параметрами $V$, які в особливий період суттєво залежать від дій противника, погодних умов, дорожніх умов під час організації і здійснення комплектування тощо. Усе це впливає на рішення особи, що приймає рішення (ОПР) в системі кадрових органів.

Загалом, завдання синтезу структури системи i підсистеми управління системою кадрових органів звичайно формулюють залежно від докладнішого аналізу: конкретних умов розв'язання проблеми; стратегічного завдання; наявного часу для вирішення завдання; досвіду спеціалістів системи кадрових органів; переваг особи, що приймає головне рішення під час створення системи. До того ж можуть виникати і розглядатися альтернативні варіанти, зокрема варіанти модернізації існуючої системи, наприклад, часткової або більш повної.
Математичне формулювання завдання синтезу структури системи і підсистеми управління системою кадрових органів. Формулювання завдання синтезу системи кадрових органів виникає у тому випадку, коли потрібно побудувати систему 3 урахуванням вимог, яким вона має задовольняти. Ці вимоги визначаються, наприклад, у вигляді показника ефективності функціонування системи кадрових органів $C=\left\{c_{z}, c_{z-1}, \ldots, c_{1}\right\}$, тобто показника ефективності комплектування особовим складом військ та складових параметрів цього показника.

Необхідно підкреслити, що синтез системи кадрових органів для досягнення мети іiі створення може бути реалізований різними за складністю способами. Тому доцільно розглянути два типи формулювання завдань синтезу цієї системи, а саме:

а) традииіійний, що спрямований на максимізацію показника ефективності комплектування військ особовим складом цією системою, через оптимізацію структури системи з їі внутрішніми параметрами $S=\left\{s_{1}, s_{2}, \ldots, s_{r}\right\}$ або шляхом оптимізації підсистеми управління 3 iii параметрами управління системою у вигляді $X=\left\{x_{1}, x_{2}, \ldots, x_{q}\right\}$;

б) перспективний, що спрямований на максимізацію показника ефективності комплектування військ особовим складом за допомогою оптимізації як структури системи з іiі внутрішніми параметрами у вигляді $S=\left\{s_{1}, s_{2}, \ldots, s_{r}\right\}$, так і підсистеми управління цією системою 3 певними параметрами управління у вигляді $X=\left\{x_{1}, x_{2}, \ldots, x_{q}\right\}$.

Математичні формулювання цих способів синтезу в компактному вигляді можна представити формулами:

a) традиційний алгоритм синтезу удосконаленої системи кадрових органів:

$$
S \Leftrightarrow \max _{S \in \Omega_{s}} C\left\{F_{s}(U, V, X)\right\} \Rightarrow\left\langle C^{*}\left\{F_{s}\right\}\right\rangle X^{*} \Leftrightarrow \max _{X \in \Omega_{x}} C\left\{F_{s}(U, V, X)\right\} \Rightarrow\left\langle C^{*}\left\{F_{s}\right\}\right\rangle .
$$


б) алгоритм синтезу перспективної системи кадрових органів:

$$
S^{*} \cap X^{*} \Leftrightarrow \max _{\left[S \in \Omega_{s}\right]\left[X \in \Omega_{x}\right]} C\left\{F_{s \cap x}(U, V, X)\right\} \Rightarrow\left\langle C^{*}\left\{F_{s \cap x}\right\}\right\rangle .
$$

Алгоритм синтезу системи у вигляді, який визначено формулою (3), має сенс принципової необхідності досягати максимального рівня показника ефективності функиіонування системи $C\left\{F_{s \cap x}(U, V, X)\right\}$ через оптимізацію як параметрів $S^{*}$ структури системи, так і параметрів $X^{*}$ управління системою, для досягнення рівня показника ефективності $C^{*}$, більш високого порівняно 3 ефективністю, яку можливо досягти за допомогою альтернативного алгоритму а), який передбачає оптимізацію або параметрів $S$ структури системи, або параметрів $X$ управління.

Перспективності саме синтезу системи за варіантом б), який визначено формулою (4), сприяють чималі можливості застосування сучасних інформаційних технологій, автоматизації систем управління i швидкодіючої комп'ютерної техніки для оперативного збору і обробки значних обсягів інформаційних потоків, 3 метою високоефективного, оптимального, управління багатофункціональною системою, функціональні елементи, об'єкти управління і споживачі матеріально-технічних потоків якої розташовані на значних відстанях від центру управління системою.

Варіант цільової функції системи кадрових органів. У якості одного з варіантів загальної цільової функції системи кадрових органів доцільно обрати вектор-показник $C=\left\{c_{z}, c_{z-1}, \ldots, c_{1}\right\}$ у вигляді

$$
Y_{j} \geq Y_{j}^{0} ; T_{j} \leq T_{j}^{0} ; \varphi_{j} \leq \varphi_{j}^{0} ; j \forall[z,(z-1),(z-2),(z-3),(z-4)] .
$$

Алгоритм синтезу перспективної системи кадрових органів у вигляді, який визначено формулою (4), може досягати максимального рівня показника ефективності функціонування системи кадрових органів $C\{F(U V X)\} \quad$ шляхом оптимізації як параметрів $S^{*}$ структури системи, так і параметрів управління $Y^{*}$ системою, $з$ метою досягнення рівня ефективності $C^{*}$ більш високого в порівнянні $з$ ефективністю, яку можливо досягти за допомогою альтернативного алгоритму, (варіант $a$ ), який передбачає оптимізацію або параметрів $S$ структури системи, або параметрів $Y$ управління в системі кадрових органів.

$$
C=\prod_{j}^{z}\left[\frac{Y_{j} T_{j}^{0} \varphi_{j}^{0}}{T_{j} Y_{j}^{0} \varphi_{j}}\right]^{z-j+1},(5)
$$

де $\Pi_{j}^{z}[]^{z-j+1}-$ ознака перемноження співмножників від $j$-го до $z$-го номера;

$z$ - кількість видів спеціальностей, що потрібні для комплектування військ;

$Y_{j} / T_{j}-\quad$ кількість спеціалістів $j$-ї спеціальності мобілізованої за час $T_{j}$;

$Y_{j}^{0} / T_{j}^{0}$ - потрібна кількість спеціалістів j-ї спеціальності, яких необхідно мобілізувати за визначений час $T_{j}^{0}$;

$\varphi_{i} / \varphi_{i}^{0}-$ реальні фінансові витрати на комплектування військ особовим складом $j$-ї спеціальності, які нормовані заданим обсягом для виконання цього завдання.

Задача оптимізації комплектування військ особовим складом від $z-і ̈$ до 1-ї спеціальності, за умов, що $z$-а спеціальність має найбільший рівень важливості, полягає в досягненні такої сукупності співмножників у складі цільової функції (5), який відповідає максимуму цієї функції. Це $є$ критерієм оптимізації комплектування у вигляді

$$
C^{*}=\max _{j} \Pi_{j=1}^{z}\left[\frac{Y_{j} T_{j}^{0} \varphi_{j}^{0}}{T_{j} Y_{j}^{0} \varphi_{j}}\right]^{z-j+1}
$$

за обмеженнями, наприклад, для 5-ти найбільш важливих спеціальностей у вигляді:

\begin{abstract}
Висновок. Перспектива синтезу системи та оптимізації процесу комплектування збройних сил особовим складом сприяють чималій можливості застосування сучасних інформаційних технологій, а саме: автоматизованої системи управління i комп'ютерної техніки для оперативного збору та обробки значних обсягів інформаційних потоків 3 метою високоефективного оптимального управління багатофункціональною системою кадрових органів, яка містить структурні функціональні елементи, об'єкти управління і військові частини для комплектування в системі, які розташовані на значних відстанях від центру управління системою комплектування збройних сил.
\end{abstract}




\section{СПИСОК ВИКОРИСТАНОЇ ЛІТЕРАТУРИ}

1. Глушков В. М. Кібернетика. Питання теорії i практики. (Наука. Світогляд. Життя). Москва : Наука, 1986. 488 с.

2. Кириченко I. О., Р Раскін Л. Г. Математичні основи теорії вогневих дуелей : монографія. Харків : Військовий інститут ВВ МВС України, 2005. 292 c.

3. Плюта В. А. Сравнительный многомерный анализ в экономических исследованиях: методы таксономии и факторного анализа / пер.с пол. В.В. Иванова. Москва : Статистика, 1980.

4. Саати Т., Кернс К. Аналитическое планирование: Организация систем / пер. с англ. Р. Г. Вачнадзе. Москва : Радио и связь, 1998. $223 \mathrm{c}$.

5. Барабащук В. И., Мирошниченко В. И.

Креденцер Б. П., Планирование эксперимента в технике / под ред. Б. П. Креденцера. Киев : Техника, 1994. 203 с.

6. Ніколайчук М. В.,

Терещенко О. O. Ідентифікація ризиків підприємства URL: http://intkonf/org/ nikolaychyk - mv-den-prof- tereschenko-oo-identifikat

siya-rizikivpidpriemstva// (дата звернення: 04.06.2019).

7. Крикун П. М., Павленко В. І., Полякова О. В., Алгоритм безпеки. Оборонний вісник. 2018. № 7.

8. Дэвид Парментер. Ключевые показатели эффективности. Разработка, внедрение и применение решающих показателей. Москва : Олимп-бизнес. 2007. 258 с. ISBN 978-5-96930106-1.

9. Приходченко Л. Л. Щодо складності застосування показників оцінювання ефективності державного управління: теорія і практика. Державне будівниитво. Харків, 2009. №1 URL: http://nbuv.gov.ua/UJRN/ DeBu_2009_1_9 (дата звернення: 06.06.2019).

10. Ключові показники ефективності. Матеріал 3 Вікіпедії. URL: https://uk.wikipedia.org/wiki/ Ключові - показники ефективності (дата звернення: 04.06.2019).

11. Asmar L., Rabe M., YeeLow C. Framework for the agile development of innovative ProductService-Systems for existing physical rehabilitation systems. Procedia Manufacturing. 2018. № 24. URL: https://www.sciencedirect.com/science/ article/pii/ S2351978918305663?\%3Dihub\#! (дата звернення: 05.06.2019).

Стаття надійшла до редакційної колегії 16.10.19

\section{Methodical approach to the formulation of the problem of synthesis and evaluation of the effectiveness of the functioning of a promising system of personnel bodies during the manning troops with personnel}

\section{Annotation}

At the present-time stage development of the Armed Forces of Ukraine, the existing system of manning troops needs to be improved. The main task of a promising system of personnel, unlike to the existing one, is to prevent the negative effects of some factors on the full-fledged staffing of qualified personnel after training, retraining and mobilization activities in a special period with minimal time and finances.

The dynamics of growth of modern requirements for the mobilization subsystem, in order to comprehensively staff the Armed Forces, and real practice of staff mobilization system in recent years, require updating the staffing system on a scientific basis. The lack of recommendations for improving the system of personnel bodies causes a problem that needs to be addressed.

The purpose of the article is to highlight a new methodological approach to the formulation of the problem of synthesis and evaluation of the effectiveness of the functioning of a promising system of personnel bodies for better manning of troops with personnel.

The prospect of system synthesis and optimization of the process of manning the Armed Forces contribute to a wide range of opportunities to the use of modern Information Technologies. Namely: an automated control system and computer equipment for the rapid collection and processing of large amounts of information flows in order to highly efficient and optimal control of a multifunctional system of personnel bodies. The system includes structural functional elements, control facilities and military units located at considerable distances from the control center of the Armed Forces manning system.

Keywords: manning of troops; system of personnel bodies; system synthesis; efficiency of functioning. 